\title{
Орфоэпические ошибки жителей города Нерюнгри
}

\author{
Болтрукевич М., ученица, \\ МОУ Гимназия №1 г. Нерюнгри
}

Научный руководитель: учитель русского языка и литературы Буиман Е.A.

Чаще всего ошибки в нашей речи связаны с ударением. Поэтому тема нашей исследовательской работы звучит именно так: «Орфоэпические ошибки жителей города Нерюнгри».

Гипотеза: анализ и классификация орфоэпических ошибок, допущенных горожанами, способствует повышению собственной речевой культуры и помогает в подготовке к сдаче ЕГЭ по русскому языку.

Объект исследования - устная речь жителей города. Предмет исследования орфоэпические ошибки в речи нерюнгринцев.

Цель нашей работы - проанализировать конкретные речевые материалы с точки зрения литературной орфоэпической нормы.

Поставленная цель требует решения следующих задач:

- $\quad$ Познакомиться с понятием орфоэпической нормы

- Классифицировать орфоэпические ошибки жителей города Нерюнгри

Основные методы исследования: наблюдение и сравнительный анализ.

Как известно, произносительная ошибка связана с нарушением норм орфоэпии.

Она проявляется только в устной речи. Орфоэпические нормы изучает специальный раздел языкознания - орфоэпия (греч. orthos - правильный и ероs - речь). Орфоэпией называют и совокупность правил литературного произношения.

Анализ специальной литературой позволил выделить нам три основных типа ошибок нерюнгринцев:

- Ошибочное ударение

- Неоправданная вставка звуков

- Ошибочное устранение звуков

Изучая речь горожан, мы отметили ряд слов с неверным ударением, наиболее часто употребляемых нерюнгринцами. Нам представилось интересным изучить речь школьников, а именно учащихся 6 «А» класса. Мы проверили, знают ли они нормы произношения этих слова. И вот какие результаты были получены. В опросе участвовал 31 человек.

- $\quad$ красивЕе - 9

- $\quad$ квАртал -11

- свеклА - 7

- бАловать -12

- жАлюзи - 5

- укрАинский - 9

- кухОнный - 5

- дЕньгами - 5

В процессе работы мы познакомили ребят с некоторыми нормами языка, так для всех учащихся нашего класса стало открытием, что глагол включИть (равно как и 
отключИть) во всех формах имеет ударение на последний (а во множественном числе на предпоследний) слог: включИм, включИшь, включИте, включАт.

Самой же распространённой ошибкой гимназистов (да и большинства россиян, пожалуй) оказался глагол «звонить» во всех его формах.

Хотелось бы, чтобы наши сограждане помнили и о том, что в словах шАрфы, бАнты и тОрты ударение падает на первый слог.

Иногда в нашей речи встречается неоправданная вставка звуков. Или понаучному - эпентеза. Имеет место и диереза - ошибочное устранение звуков.

- поДскользнуться (эпентеза)

- чЕрезвычайный (эпентеза)

- нет брелка (брелОка) (диереза)

- тыща (тыСЯЧа) (диереза)

Размышляя над практической значимостью проекта, вспомнились таблички, в московском метро, с призывом правильно произносить слова. Мы решили взять эту идею за основу и повесили такие таблички в гимназии. Обновление их планируется каждые 2 недели.

Однако, несмотря на стремление сделать свою речь безупречной, можно вполне согласиться со словами великого русского поэта Александра Сергеевича Пушкина:

Как уст румяных без улыбки,

Без грамматической ошибки

Я русской речи не люблю.

Быть может, на беду мою...

\section{Список литературы}

1. Розенталь Д.Э. «Словарь лингвистических терминов». М., 1992.

2. Ушаков Д.Н. «Толковый словарь русского языка». М., 1985.

3. «Русская грамматика». 1 том. М., 1986.

4. http://dic.academic.ru

5. http://www.slovari.ru

\section{Повышение качества языковой подготовки студентов первого курса посредством чтения аутентичных текстов}

Будаева Е.Д., студентка,

Технический институт (филиал) Северо-Восточного федерального университета, 2. Нерюнгри

E-mail: katerina-875@mail.ru

Научный руководитель: к.филол.н. Павлова Т.Л.

В методике преподавания иностранного языка чтение, как речевой вид деятельности, занимает особенное место. Здесь оно занимает лидирующую позицию по своей доступности и значимости. Как правило, предметом чтения является чья-либо мысль, которую мы идентифицируем посредством зрительного восприятия текста. 